\author{
ACTA UN IVER S T A T IS LODZIEN S IS \\ FOLIA OECONOMICA 5(325) 2016
}

http://dx.doi.org/10.18778/0208-6018.325.01

Anna Danuta Weszczak*

\title{
ZASTOSOWANIE MODELI PANELOWYCH DO BADANIA BEZPIECZEŃSTWA RUCHU DROGOWEGO W POLSCE W LATACH 2001-2012
}

\begin{abstract}
Streszczenie. Przedmiotem artykułu jest scharakteryzowanie poziomu bezpieczeństwa ruchu drogowego w poszczególnych regionach Polski w latach 2001-2012 przy wykorzystaniu modeli ekonometrycznych. W opracowaniu zostanie podjęta próba wyznaczenia społeczno-ekonomicznych determinantów bezpieczeństwa ruchu drogowego. Na podstawie literatury przedmiotu oraz raportów instytucji zajmujących się badanym zagadnieniem, a także uwzględniając dostępność danych liczbowych, za zmienne takie uznano: wydatki jednostek samorządowych w Dziale 600 - Transport i łączność, jakość dróg, wskaźnik zmotoryzowania społeczeństwa, długość sieci drogowej oraz udział pojazdów ciężkich w ogóle pojazdów. Badaniu zostały poddane trzy wskaźniki zagrożenia: liczba ofiar śmiertelnych na $1 \mathrm{mln}$ mieszkańców, liczba ofiar śmiertelnych na 1 mln pojazdów oraz liczba ofiar śmiertelnych na 100 wypadków drogowych. Do estymacji parametrów równania wykorzystano modele panelowe - modele $\mathrm{z}$ efektami stałymi (fixed effect model, FEM) oraz modele z efektami losowymi (random effect model, REM).
\end{abstract}

Slowa kluczowe: transport, bezpieczeństwo ruchu drogowego, modele panelowe.

JEL: C23, R41.

\section{WPROWADZENIE}

Transport jest integralnym elementem każdej działalności gospodarczej. Przede wszystkim, co wynika z samego jego przeznaczenia, infrastrukturalna sieć połączeń transportowych spaja przestrzeń, umożliwiając szeroko rozumiane kontakty międzyludzkie w sferach: gospodarczej, społecznej, kulturowej i prywatnej (Domańska 2006). Z jednej strony, jego rozwój jest niewątpliwie pozytywnym zjawiskiem, gdyż determinuje rozwój całej gospodarki, z drugiej jednak prowadzi do powstawania tzw. kosztów zewnętrznych transportu, które stanowią istotną barierę jej funkcjonowania. W latach 1995 i 2000 w Norwegii, Szwajcarii oraz państwach UE-15 przeprowadzono badania tych kosztów. Wyniki zostały opracowane przez INFRAS i IWW. Zgodnie z raportami External cost of transport (Schreyer 2004) za najważniejsze zewnętrzne koszty transportu należy uznać:

\footnotetext{
*Uniwersytet Łódzki, Wydział Ekonomiczno-Socjologiczny, annaweszczak@interia.pl
} 
- wypadki będące nieodłącznym elementem wszystkich gałęzi transportu, najczęściej jednak występujące w transporcie drogowym;

- hałas pochodzący od środków transportu, którego długotrwałe oddziaływanie na człowieka może implikować silny stres, choroby serca, zaburzenia krążenia krwi lub przemianę hormonalną;

- zanieczyszczenie powietrza spowodowane wydzielaniem przez środki transportu spalin, głównie tlenków węgla (CO), azotu (NO), a także pyłów;

- zmiany klimatu;

- zmiany w przyrodzie i krajobrazie negatywnie oddziałujące na ekosystem i populację zwierząt ginących pod kołami samochodów oraz tracących swoje naturalne środowisko;

- dodatkowe koszty w obszarach miejskich powstające w związku z koniecznością wytyczenia bezpiecznych przejść i dróg dla niechronionych uczestników ruchu drogowego (chodników, ścieżek rowerowych, przejść dla pieszych i rowerzystów);

- dodatkowe koszty związane z produkcją energii i środków transportu oraz budową i utrzymaniem infrastruktury transportowej. Są one związane m.in. z koniecznością dostarczenia energii do transportu oraz z produkcją i utrzymaniem zarówno środków transportu, jak i infrastruktury transportowej;

- koszty kongestii, które oznaczają nie tylko stratę czasu, ale także zwiększoną emisję spalin podczas jazdy w warunkach zwiększonego zatłoczenia dróg.

Celem niniejszego opracowania jest scharakteryzowanie poziomu bezpieczeństwa ruchu drogowego ${ }^{1} \mathrm{w}$ poszczególnych regionach Polski oraz identyfikacja i analiza jego determinantów. W badaniu weryfikowana jest hipoteza, zgodnie z którą zwiększenie nakładów inwestycyjnych implikuje zmniejszenie wypadkowości drogowej². Do pomiaru jej poziomu wykorzystano trzy wskaźniki zagrożenia definiowane przez KRBRD, a mianowicie: wskaźnik demograficzny liczony jako stosunek liczby ofiar śmiertelnych do liczby mieszkańców (w mln osób) oraz dwa wskaźniki ciężkości (I i II), które stanowią stosunek

${ }^{1}$ Termin bezpieczeństwo ruchu drogowego odnosi się do zbioru zasad dotyczących bezpiecznego poruszania się po drogach oraz odpowiednich warunków ruchu drogowego, organizacji ruchu drogowego, nadzoru ruchu. To także zagadnienia związane ze szkoleniami i egzaminowaniem kierowców, ratownictwem medycznym, stanem technicznym pojazdów i zakresem ich kontroli, a także z kreowaniem właściwych zachowań wszystkich uczestników ruchu drogowego;

${ }^{2}$ Wypadki drogowe to niedające się przewidzieć zdarzenie, mające miejsce w ruchu drogowym, pozostające w związku przyczynowym z ruchem drogowym, wynikające z naruszenia zasad bezpieczeństwa obowiązujących $\mathrm{w}$ tym ruchu, którego skutkiem są spowodowane nieumyślnie obrażenia ciała powodujące naruszenie czynności narządu ciała lub rozstrój zdrowia trwające dłużej niż 7 dni (tzw. średni wypadek drogowy), śmierć albo ciężki uszczerbek na zdrowiu (tzw. ciężki wypadek drogowy) (Rajchel, Nowakowski 2006). W odróżnieniu od kolizji drogowej powodującej jedynie szkody w mieniu, wypadek drogowy musi powodować naruszenie stanu zdrowia osoby w nim uczestniczącej. 
liczby ofiar śmiertelnych do 100 wypadków drogowych (I) oraz do liczby pojazdów w mln sztuk (II).

Wyniki przeprowadzonego badania ekonometrycznego mogą stanowić wsparcie dla działań ukierunkowanych na zmniejszenie liczby zdarzeń drogowych inicjowanych przez odpowiednie instytucje, ale także przez samych uczestników ruchu.

Zgodnie ze statystykami prowadzonymi przez Światową Organizację Zdrowia (WHO 2013) na całym świecie co 6 sekund dochodzi do zdarzenia drogowego, zaś co 30 sekund ma miejsce śmiertelny wypadek. Oznacza to, iż każdego roku na skutek wypadków drogowych życie traci ok. 1,24 mln osób, a 20-50 mln zostaje rannych. Przewiduje się, iż w kolejnych latach liczba ofiar śmiertelnych może się podwoić.

\section{KOSZTY WYPADKÓW DROGOWYCH}

Wypadki drogowe generują olbrzymie straty materialne obciążające całą gospodarkę oraz indywidualne koszty społeczne w postaci traumy, poczucia bólu i cierpienia nie tylko uczestników zdarzenia, ale także ich rodzin. Straty społeczne jednakże to nie tylko urazy natury psychicznej, ale także pogorszenie sytuacji finansowej osoby poszkodowanej i jej rodziny ze względu na trwałą lub tymczasową niezdolność do pracy, konieczność pokrycia kosztów medycznych, a w przypadku kalectwa kosztów trwałej opieki nad ofiarą wypadku. Stratami społecznymi są też koszty ponoszone przez pracodawców wynikające z absencji chorobowej lub utraty doświadczonego pracownika. W dłuższej perspektywie czasowej, konsekwencją są straty budżetu państwa, które wynikają zarówno $\mathrm{z}$ utraty przyszłej produkcji, jak również z konieczności finansowania przez rząd opieki medycznej i psychologicznej, programów pomocy społecznej i administracji w postaci służb policyjnych, straży pożarnej, sądownictwa, więziennictwa. Ciężkie obrażenia ciała w wyniku wypadku drogowego mogą skutkować długotrwałą bądź dożywotnią niezdolnością do pracy, co nakłada na państwo obowiązek wypłaty powypadkowych rent inwalidzkich lub rent rodzinnych dla osób, które straciły członka rodziny.

Złożony charakter problemu powoduje, iż dokonanie prawidłowej wyceny kosztów zdarzeń drogowych jest niezwykle skomplikowane. Od 2012 roku w Polsce stosuje się metodę wyceny PANDORA 2013, która obejmuje wycenę wszystkich zdarzeń drogowych, a zatem zarówno wypadków, jak i kolizji. Metoda ta, będąca jeszcze w fazie rozwoju, obejmuje wycenę kosztów jednostkowych ofiar śmiertelnych, lekko i ciężko rannych oraz strat materialnych. Stosowana metoda opiera się na ogólnie przyjętych praktykach z zakresu ekonomiki transportu i obejmuje następujące składowe: koszty medyczne, koszty utraconej mocy produkcyjnej (utracona produkcja), koszty uszkodzenia mienia, koszty 
administracyjne (KRBRD 2013). Zgodnie z szacunkami Instytutu Badawczego Dróg i Mostów (Jaździk-Osmólska 2013) koszty zdarzeń drogowych ukształtowały się Polsce w 2012 roku na poziomie 34,53 $\mathrm{mln}$ PLN, co stanowiło ok. 1,9\% PKB. Koszty samych wypadków drogowych sięgnęły 1,6\% PKB i wynosiły $29,37 \mathrm{mln}$ PLN, zaś pozostałe $5,16 \mathrm{mln}$ PLN to straty spowodowane kolizjami drogowymi. Z kolei jednostkowe koszty zdarzeń drogowych wynosiły w 2012 roku:

- koszt jednostkowy ofiary śmiertelnej - 2,5 mln PLN,

- koszt jednostkowy ofiary ciężko rannej - 1,1 mln PLN,

- koszt jednostkowy ofiary lekko rannej - 15 tys. PLN,

- koszt jednostkowy straty materialnej wypadku - 80 tys. PLN,

- koszt jednostkowy wypadku drogowego - 733 tys. PLN,

- koszt jednostkowy kolizji drogowej - 15 tys. PLN.

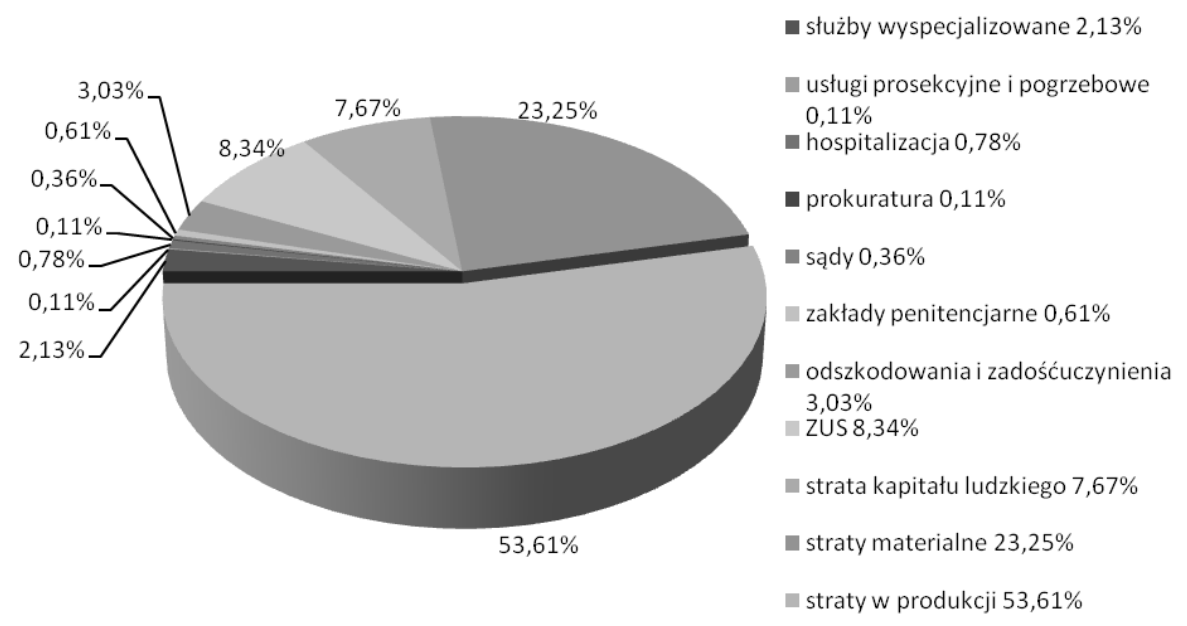

Wykres 1. Udział kosztów jednostkowych w wartości zdarzeń drogowych w Polsce w 2012 roku według metody PANDORA 2013

Źródło: opracowanie własne na podstawie: Jaździk-Osmólska (2013).

Są to koszty związane z (Wykres 1):

- pracą służb ratowniczych i policyjnych,

- kosztami leczenia oraz pomocą medyczną udzieloną na miejscu zdarzenia,

- usługami prosekcyjnymi i pogrzebem,

- kosztami postępowania karnego oraz pobytem sprawców w zakładach karnych,

- rekompensatami i rentami wypłacanymi poszkodowanym,

- szkodami w pojazdach, 
- stratami pracodawców,

- stratami gospodarczymi budżetu państwa spowodowanych zmniejszeniem produkcji i konsumpcji.

\section{CHARAKTERYSTYKA POZIOMU BEZPIECZEŃSTWA RUCHU DROGOWEGO W POLSCE}

W ostatnim dziesięcioleciu liczba zdarzeń drogowych w Polsce ulegała sukcesywnemu zmniejszaniu. Wyjątek stanowily lata 2007 i 2011, kiedy odnotowano wzrost liczby zdarzeń odpowiednio z 46876 do 49536 oraz z 38832 do 40131 . W analizowanym okresie odnotowano spadek liczby wypadków i kolizji drogowych o $31 \%$, zaś liczby ofiar śmiertelnych i rannych odpowiednio o $35 \%$ i 33\%. Najwięcej osób, aż 5 827, zginęło w 2002 roku, zaś największa liczba rannych została odnotowana w 2001 roku, kiedy to jej poziom wynosił 68194 osoby.

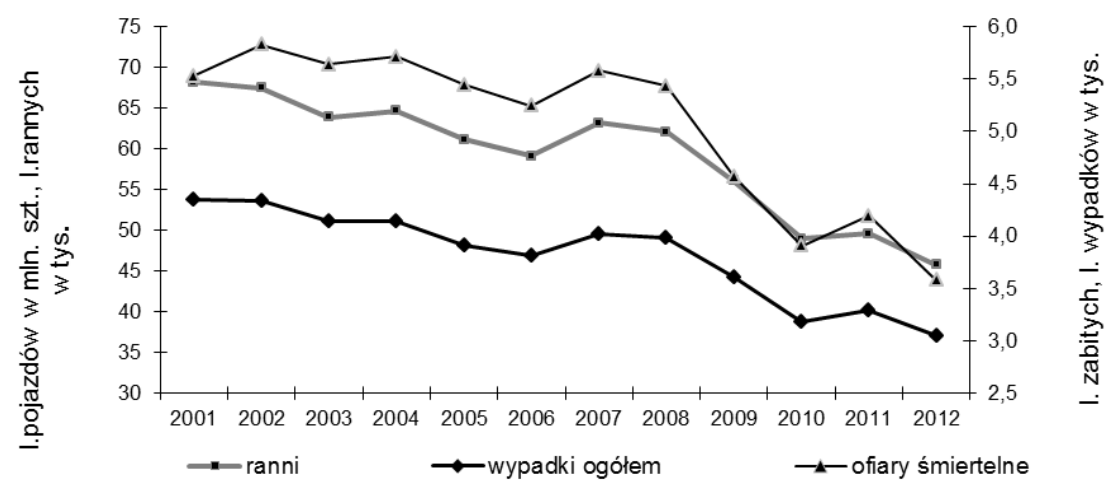

Wykres 2. Dynamika liczby wypadków drogowych oraz ich ofiar w Polsce w latach 2001-2012

Źródło: Opracowanie własne na podstawie danych z GUS (http://stat.gov.pl/).

Tak duża poprawa poziomu bezpieczeństwa mogłaby cieszyć, gdyby nie odnosić jej do pozostałych krajów Unii Europejskiej. Zgodnie z Raportem Końcowym opracowanym przez ekspertów Międzynarodowego Banku Odbudowy i Rozwoju / Banku Światowego krajom UE mającym porównywalne wskaźniki śmiertelności w latach 2001-2011 udało się ograniczyć liczbę ofiar śmiertelnych średnio o 45\%. Polska stała się jednym z państw o najwyższym wskaźniku śmiertelności na drogach, osiągając w 2012 roku poziom 93 zabitych na milion mieszkańców, podczas gdy średnia UE była niemalże dwukrotnie niższa (Wykres 3). 


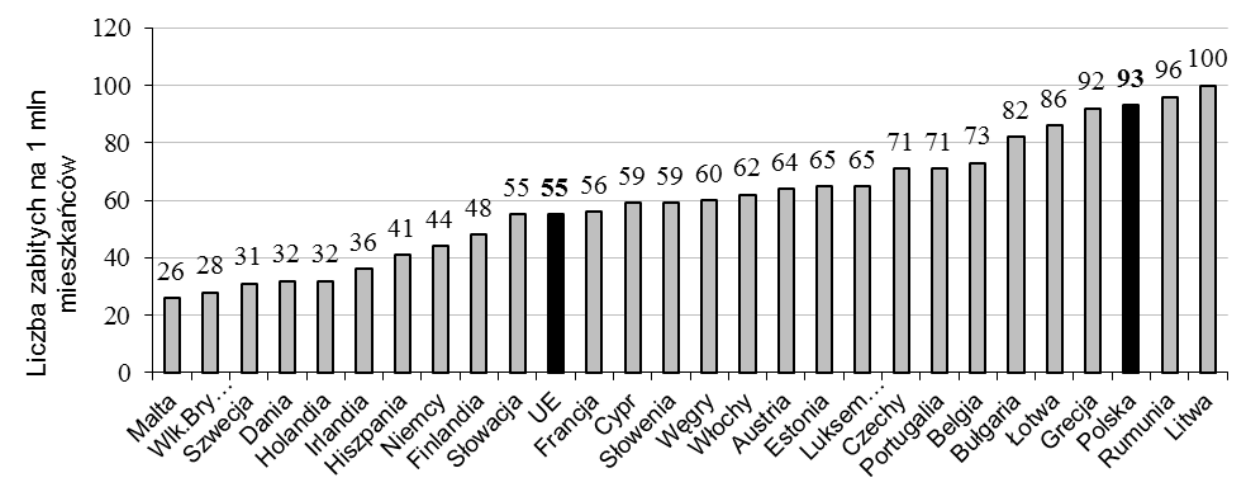

Wykres 3. Wskaźnik śmiertelności w wypadkach drogowych w 2012 roku w Unii Europejskiej

Źródło: opracowanie własne na podstawie http://ec.europa.eu/transport/road_safety/index_en.htm

Analizując przestrzenne rozmieszczenie występowania wypadków drogowych, w których ludzie stracili życie w 2012 roku, można zauważyć, iż w niechlubnej czołówce znalazły się województwa mazowieckie (584 osoby), śląskie (336) oraz wielkopolskie (315). Z kolei województwami, cechującymi się największą liczbą rannych były śląskie (5 707), mazowieckie (5 384), łódzkie (4 844), małopolskie (4 775) oraz dolnośląskie (4 263). Najbezpieczniejsze pod względem śmiertelności okazały się być województwa opolskie i lubuskie, w których zginęły odpowiednio 82 i 99 osób. W tych samych województwach oraz dodatkowo w podlaskim najmniej osób odniosło obrażenia w wypadkach.

Należy pamiętać, iż poszczególne regiony charakteryzują się różną liczbą mieszkańców, liczbą samochodów przypadającą na mieszkańca, wielkością powierzchni, natężeniem ruchu na drogach. Do celów porównawczych bardziej zasadne jest zatem operowanie tzw. wskaźnikami zagrożenia, tj. wskaźnikami ciężkości wypadków wyrażonymi jako stosunek liczby zabitych i liczby rannych na 100 wypadków lub wskaźnikami demograficznymi, które liczone są jako stosunek liczby ofiar wypadków na milion mieszkańców.

Używając wskaźnika ciężkości wypadków do oceny poziomu bezpieczeństwa w ruchu drogowym, można zauważyć, iż w 2012 roku rejonem o najwyższej liczbie ofiar śmiertelnych sięgającej 17,1 osób na 100 zdarzeń drogowych było Podlasie (Wykres 4). Niewiele lepsza sytuacja charakteryzowała województwa kujawsko-pomorskie $(16,8)$, lubelskie $(15,0)$ oraz mazowieckie $(13,1)$.

Analizując z kolei stosunek liczby osób, które poniosły śmierć w wyniku wypadków drogowych, do liczby mieszkańców danego regionu okazuje się, iż w 2012 roku najwyższy wskaźnik, sięgający aż 119 osób na 1 mln mieszkańców, został odnotowany w województwie łódzkim. 


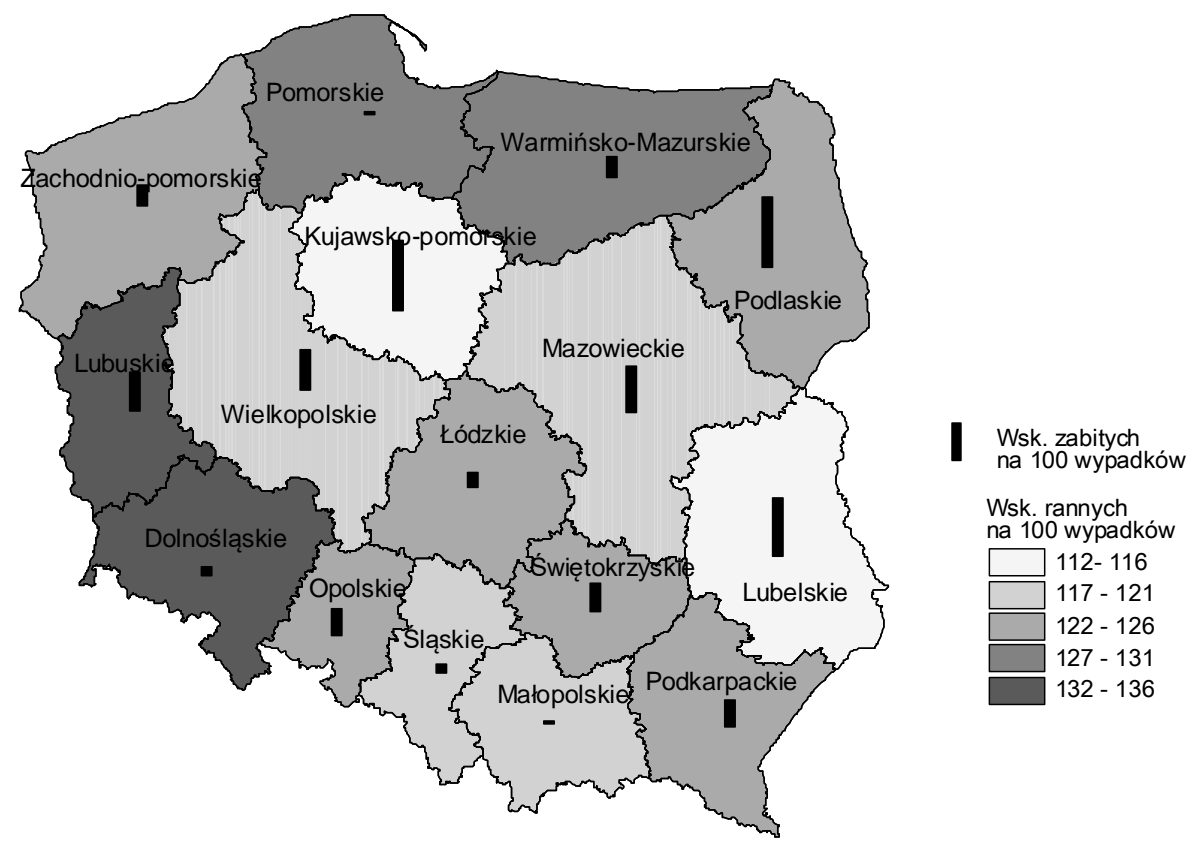

Wykres 4. Przestrzenne zróżnicowanie wskaźnika rannych oraz zabitych na 100 wypadków drogowych w 2012 roku

Źródło: opracowanie własne na podstawie danych GUS.

$\mathrm{Na}$ nieco niższym, choć również bardzo wysokim poziomie uplasowały się województwa lubelskie oraz mazowieckie, w których w wypadkach zginęło odpowiednio 112 i 111 osób na $1 \mathrm{mln}$ obywateli. Z kolei województwa śląskie, małopolskie, zachodniopomorskie oraz pomorskie charakteryzowały się najwyższym poziomem bezpieczeństwa. Omawiany wskaźnik nie przekraczał tam 80 ofiar na $1 \mathrm{mln}$ mieszkańców.

\section{PRZYKLADY DOTYCHCZASOWYCH BADAŃ Z ZAKRES BRD}

Bezpieczeństwo ruchu drogowego od wielu lat stanowi przedmiot licznych badań i analiz. Autorzy próbują odnaleźć zależności zachodzące między liczbą wypadków drogowych a określonymi czynnikami społeczno-ekonomicznymi. Przykładem może być propozycja J. Wachnickiej i L. Smolarka (2013), którzy przeprowadzili wielopoziomową analizę stochastyczną wypadkowości, łącząc modele o zasięgu krajowym z modelami regionalnymi. Podejście takie wynikało 
z faktu, iż część danych jest dostępna jedynie w ujęciu globalnym. Ogólną postać modelu można opisać wzorem:

$$
F A T A L R=\alpha * M O D E L_{\text {NATIONAL }}^{\beta_{1}} * M O D E L_{\text {NATIONAL }}^{\beta_{2}} * N P P C_{\text {NATIONAL }}^{\beta_{3}}
$$

gdzie:

FATALR - wskaźnik demograficzny wyrażony jako liczba śmiertelnych ofiar wypadków drogowych przypadająca na każde 100000 mieszkańców danego regionu,

$M O D E L_{N A T I O N A L}$ - model dla danych na poziomie narodowym,

$M O D E L_{R E G I O N A L}$ - model dla danych na poziomie regionalnym,

$N P P C_{N A T I O N A L}-$ model opisujący zmiany przeciętnego produktu narodowego per capita,

$\alpha_{1}, \beta_{1}, \beta_{2}, \beta_{3}$ - estymowane parametry.

Za czynniki opisujące poziom BRD na szczeblu regionalnym autorzy uznali: produkt narodowy per capita, gęstość zaludnienia, udział pojazdów osobowych w ogóle pojazdów, liczbę kilometrów dróg przypadającą na mieszkańca danego regionu oraz wskaźnik bezrobocia. $\mathrm{Z}$ kolei za zmienne o charakterze globalnym przyjęli udział starych pojazdów osobowych (przekraczających 10 lat) w całej flocie pojazdów oraz indeks korupcji ${ }^{3}$, którego wzrost prowadzi do poprawy poziomu bezpieczeństwa drogowego. Zgodnie z oczekiwaniami wyższy wiek pojazdów stanowi zagrożenie na drogach.

Ciekawą propozycję badania przedstawił J.I. Castillo-Manzano (2014), który potwierdził hipotezę, iż państwa dłużej należące do UE cechują się wyższym poziomem bezpieczeństwa ruchu drogowego wyrażonym jako liczba ofiar śmiertelnych przypadająca na $1 \mathrm{mln}$ mieszkańców danego regionu. W pierwszym kroku badania autor wykorzystał metodę najmniejszych kwadratów, a następnie zastosował dwuczynnikowy model panelowy FE dla 27 państw członkowskich Unii Europejskiej w latach 2000-2009. Dodatkowo autor analizował zależności zachodzące między wskaźnikiem śmiertelności a: PKB per capita, wskaźnikiem zmotoryzowania, liczbą pasażerokilometrów przypadającą na mieszkańca danego regionu, gęstością sieci drogowej, udziałem osób z wykształceniem średnim w ogóle populacji, udziałem osób młodych (między 20-34 rokiem życia) oraz osób powyżej 60 roku życia w całej populacji, a także przyjętymi ograniczeniami prędkości obowiązującymi w danym kraju. Wprowadzone zostały również dwie zmienne sztuczne: zmienna przyjmująca wartość 1 dla krajów, w których dopuszczalne stężenie alkoholu we krwi nie może przekra-

\footnotetext{
${ }^{3}$ Wyższy poziom wskaźnika korupcji oznacza mniejszą korupcję.
} 
czać promila oraz zmienna o wartości 1 dla państw stosujących system punktów karnych dla kierowców.

Z kolei Kopits i Cropper (2003), Anbarci, Escaleras i Register (2006) oraz Koren i Borsos (2013) udowodnili, iż zależność między poziomem PKB per capita a stanem bezpieczeństwa drogowego ma charakter nieliniowy. Przy niskim poziomie dochodu należy oczekiwać zwiększenia wypadkowości, która jednakże zaczyna maleć po przekroczeniu określonego poziomu bogactwa kraju.

\section{SPECYFIKACJA PODSTAWOWYCH ZALEŻNOŚCI I RÓWNAŃ MODELU BEZPIECZEŃSTWA RUCHU DROGOWEGO}

Wyznaczenie determinantów powstawania wypadków drogowych ma olbrzymie znaczenie dla gospodarki, gdyż każde zdarzenie drogowe jest przyczyną poważnych strat sięgających każdego roku ok. 2\% PKB. Głównym celem niniejszej analizy jest wskazanie oraz pomiar siły oddziaływania czynników kształtujących wskaźniki zagrożenia w ruchu drogowym. Badanie to może stanowić wsparcie $\mathrm{w}$ podejmowaniu działań ukierunkowanych na podniesienie bezpieczeństwa w ruchu drogowym w naszym kraju. Opierając się na raportach KRBRD, za podstawowe przyczyny powstawania wypadków należy uznać jazdę z nadmierną prędkością oraz błędy infrastruktury drogowej. Mimo iż występowanie nieprawidłowości na drogach bardzo rzadko podawane jest w raportach powypadkowych jako bezpośrednia przyczyna zdarzeń drogowych, to właśnie zły stan infrastruktury sprzyja popełnianiu błędów przez uczestników ruchu, stając się pośrednią przyczyną wypadków. KRBRD zwraca uwagę na takie ułomności infrastruktury drogowej jak np.:

- niewielki udział dróg o najwyższym standardzie (dróg ekspresowych i autostrad) w ogóle dróg,

- nieodpowiednia jakość dróg i nawierzchni drogowej;

- wielofunkcyjność przeważającej części głównych dróg i ulic, mieszana struktura potoków pojazdów na drogach (szybkie samochody osobowe i ciężarowe, ciągniki, rowery i ruch pieszy) (KRBRD 2013).

Powyższy raport oraz litera przedmiotu stanowiły podstawę do wyznaczenia zmiennych objaśniających poziom wypadkowości w Polsce. Za zmienne egzogeniczne uznano:

- wydatki jednostek samorządowych w dziale 600 - Transport i łączność (wydatki),

- jakość dróg mierzoną jako udział liczby kilometrów dróg w stanie wymagającym natychmiastowego remontu w ogólnej liczbie kilometrów (złe_drogi); 
- udział pojazdów ciężkich w ogóle pojazdów samochodowych, przy czym za ogół pojazdów uznano samochody osobowe, ciężarowe oraz motocykle (UPC),

- wskaźnik zmotoryzowania społeczeństwa wyrażony liczbą pojazdów przypadającą na 1000 mieszkańców danego regionu (zmotor);

- długość sieci drogowej wyrażonej liczbą kilometrów dróg publicznych o twardej nawierzchni przypadającej na $100 \mathrm{~km}^{2}$ powierzchni regionu (drogi).

$\mathrm{Na}$ poziom bezpieczeństwa mogą mieć również wpływ warunki atmosferyczne oraz zachowanie kierowców wynikające ze zmęczenia, nadmiernej brawury, agresji, niedostatecznych umiejętności (wadliwy system szkoleń). Czynniki te nie zostały uwzględnione w proponowanych modelach ze względu na brak możliwości uzyskania takich danych liczbowych.

Przeprowadzono je dla trzech różnych wskaźników zagrożenia:

- wskaźnik demograficzny - będący stosunkiem liczby ofiar śmiertelnych w wypadkach drogowych na danym obszarze do liczby osób zamieszkujących ten obszar:

$$
\text { wsk.demograficzny }=\frac{\text { liczba ofiar śmiertelnych }}{1 \text { mln mieszkańców }}
$$

- ciężkość wypadków I - będący stosunkiem liczby ofiar śmiertelnych do liczby wypadków drogowych, w których brały udział:

$$
\text { ciężkość wypadków } \mathrm{I}=\frac{\text { liczba ofiar śmiertelnych }}{100 \text { wypadków drogowych }}
$$

- ciężkość wypadków II - będący stosunkiem liczby ofiar śmiertelnych do liczby pojazdów zarejestrowanych $\mathrm{w}$ danym regionie:

$$
\text { ciężkość wypadków II }=\frac{\text { liczba ofiar śmiertelnych }}{1 \mathrm{mln} \text { pojazdów }}
$$

Rozwój nauki, możliwość korzystania z wyspecjalizowanego oprogramowania komputerowego oraz większa dostępność danych liczbowych stwarza dogodne warunki do czerpania $\mathrm{z}$ nowoczesnych metod badawczych. Jedną z nich jest szacownie modeli przy użyciu danych panelowych (czasowo-przekrojowych), czyli takich, „(..) które obserwowalne są w co najmniej dwóch wymiarach. Najlepszym przykładem danych panelowych są dane prze- 
strzenno-czasowe, tzn. obserwowane na wielu obiektach, obszarach, przez wiele okresów" (Kufel 2007). Stosowanie tego typu modeli umożliwia przeprowadzenie rozbudowanych analiz i uzyskanie szczegółowych informacji. Ich konstrukcja opiera się na założeniu o niezmienności parametrów stojących przy zmiennych objaśniających względem obiektów i czasu. Heterogeniczność obiektów lub zróżnicowanie modelowanego zjawiska w czasie uwzględnia się w tego typu modelach poprzez zróżnicowanie względem obiektów (i/lub czasu) składnika losowego albo, w zależności od założeń, wyrazu wolnego (Dańska-Borsiak 2011). Budowa modelu opiera się na złożeniu, iż występowanie heterogeniczności jest uwarunkowane przez pominięcie w modelu zmiennych mogących mieć istotny wpływ na kształtowanie się estymowanego zjawiska. Ich wpływ może być specyficzny dla poszczególnych obiektów i stały w czasie bądź stały w czasie, lecz ulegający zmianom w obiektach. Zakłada się, iż łączne oddziaływanie czynników nieuwzględnionych w szacowanym modelu jest istotne, w przeciwieństwie do ich wpływu indywidualnego. Ponadto efekty te są zawarte w składniku losowym i nie są skorelowane ze zmiennymi egzogenicznymi.

Modele panelowe estymowane są metodami opartymi na klasycznej lub uogólnionej metodzie najmniejszych kwadratów (KMNK lub UMNK). Model z efektami grupowymi, będący modelem statycznym, opisany jest wzorem:

$$
y_{i t}=x_{i t}^{T} \beta+\left(\alpha_{i}+\varepsilon_{i t}\right),
$$

gdzie:

$i$ - numer obiektu np. regionu, przedsiębiorstwa $(i=1)$,

$t$ - numer okresu;

$x_{i t}^{T}=\left[x_{1 i t}, \ldots, x_{K i t}\right]-$ wektor zmiennych objaśniających,

$\beta=\left[\beta_{1}, \ldots, \beta_{K}\right]^{T}-$ wektor parametrów strukturalnych,

$u_{i t}=\alpha_{i}+\varepsilon_{i t}-$ składnik losowy składający się z właściwej dla danego obiektu stałej w czasie części zwanej efektem grupowym $\left(\alpha_{i}\right)$ oraz właściwego składnika losowego $\left(\alpha_{i t}\right)$.

Efekty grupowe mogą być utożsamiane z wyrazem wolnym, zróżnicowanym względem obiektów bądź jako składowa składnika losowego. Estymację tych pierwszych wykonuje się przy zastosowaniu modeli ze zmiennymi sztucznymi, zwanymi także modelami z efektami nielosowymi, ustalonymi, stałymi (ang. fixed effect models FEM). Można je wyrazić wzorem:

$$
y_{i t}=\alpha_{i}+x_{i t}^{T} \beta+\varepsilon_{i t},
$$


Wyraz wolny $\alpha_{i}$ jest zróżnicowany w poszczególnych obiektach i odnosi się do nieobserwowalnego oraz nieuwzględnionego w równaniu regresji efektu charakterystycznego dla $i$-tego obiektu. $Z$ kolei parametry stojące przy zmiennych objaśniających dla wszystkich okresów i obiektów są identyczne. Efekty zmian zmiennych $x_{k i t}$ są zatem jednakowe we wszystkich okresach i dla wszystkich obiektów, przeciętny poziom zjawiska może być jednakże zróżnicowany dla różnych obiektów.

Drugą grupą modeli stanowią modele $\mathrm{z}$ dekompozycją składnika losowego nazywane także modelami $\mathrm{z}$ efektami losowymi (ang. random effect models, REM). Modele te przybierają następującą postać:

$$
y_{i t}=\alpha+x_{i t}^{T} \beta+\left(\alpha_{i}+\varepsilon_{i t}\right)=\alpha+x_{i t}^{T}+u_{i t},
$$

W modelach REM przyjmuje się założenie, iż w skład składnika losowego $u_{i t}$ wchodzą stały w czasie efekt grupowy $\alpha_{i}$ oraz zmienny w czasie i po obiektach, tzw. właściwy składnik losowy $\varepsilon_{i t}$. Oba elementy składnika losowego są niezależne zarówno od zmiennych $x_{k i t}$, jak i od siebie nawzajem.

Dokonania wyboru pomiędzy modelami FEM i REM dokonuje się zwykle na podstawie testu zaproponowanego przez J.A. Hausmana. Na jego podstawie weryfikowana jest hipoteza zerowa, zgodnie z którą ,(...) estymator UMNK jest zgodny i najefektywniejszy. $Z$ drugiej strony, estymator wewnątrzgrupowy $\hat{\beta}_{W}$ jest zgodny niezależnie od tego, czy H0 jest prawdziwa, czy też nie, ponieważ wszystkie stałe $\mathrm{w}$ czasie efekty są wyeliminowane $\mathrm{z}$ modelu. Zatem możemy skonstruować $q=\hat{\beta}_{W}-\hat{\beta}_{U M N K}$, dla którego $V(q)=V\left(\hat{\beta}_{w}\right)-V\left(\hat{\beta}_{U M N K}\right)$. Wynika z tego możliwość zastosowania $m=\hat{q}^{\prime}[\hat{V}(\hat{q})]^{-1} \hat{q}$ jako statystyki, która przy prawdziwości H0 ma rozkład $\chi^{2} \mathrm{z}$ k stopniami swobody, gdzie k określa wymiar $\beta$ " (Maddala 2008).

\section{REZULTATY ESTYMACJI MODELU}

Wszystkie wyliczenia przeprowadzono w programie Gretl, zaś uzyskane wyniki zaprezentowano w Tabeli 1 . Szacunki były prowadzone dla logarytmów zmiennych. Modele dla wszystkich wskaźników zagrożenia miały jednakową specyfikację wyjściową, przy czym tablica zawiera jedynie zmienne istotne statystycznie. Do estymacji wykorzystano zarówno modele z efektami stałymi, jak i modelami z dekompozycją składnika losowego. Ostatecznie na podstawie testu Hausmana dokonano wyboru modelu FEM. 
Współczynnik determinacji, otrzymany w wyniku przeprowadzonej estymacji równań, ukształtował się na wysokim poziomie przekraczającym $85 \%$ w przypadku modelowania liczby zabitych na $1 \mathrm{mln}$ pojazdów oraz liczby zabitych na 100 wypadków drogowych. Niższy, choć wciąż wysoki poziom dopasowania modelu otrzymano dla liczby zabitych na $1 \mathrm{mln}$ mieszkańców. Otrzymany $\mathrm{w}$ badaniu kierunek oddziaływania wszystkich zmiennych na zmienną objaśnianą jest zgodny z oczekiwaniami.

Można zauważyć, iż wyniki estymacji modeli 1 i 2 są do siebie bardzo podobne. W obu przypadkach zwiększenie udziału pojazdów ciężarowych w ogóle pojazdów samochodowych (zmot) w największym stopniu przyczyni się do wzrostu śmiertelności na skutek wypadków drogowych. Potwierdza to wnioski KRBRD, iż ułomna infrastruktura drogowa, która charakteryzuje się mieszaną strukturą potoków pojazdów, negatywnie wpływa na poziom bezpieczeństwa.

Tabela 1. Wyniki estymacji równań modeli bezpieczeństwa ruchu drogowego dla lat 2001-2012

\begin{tabular}{|c|c|c|c|c|}
\hline $\begin{array}{c}\text { Parametry równania oraz } \\
\text { wsp. determinacji }\end{array}$ & $\begin{array}{c}\text { Nazwa } \\
\text { parametru }\end{array}$ & $\begin{array}{l}\text { Model 1: } \\
\text { Zabici na mln } \\
\text { mieszkańców }\end{array}$ & $\begin{array}{c}\text { Model 2: } \\
\text { Zabici na mln } \\
\text { pojazdów }\end{array}$ & $\begin{array}{l}\text { Model 3: } \\
\text { Zabici na } 100 \\
\text { wypadków }\end{array}$ \\
\hline Wsp. determinacji & $\mathrm{R}^{2}$ & 0,73 & 0,86 & 0,85 \\
\hline Wyraz wolny & const & 5,61 & 8,96 & 10,50 \\
\hline $\begin{array}{l}\text { Wydatki jednostek samo- } \\
\text { rządowych w Dziale } 600\end{array}$ & wydatki & $-0,11 * * *$ & $-0,11 * * *$ & $-0,73 * * *$ \\
\hline $\begin{array}{l}\text { Dział złych dróg w ogólnej } \\
\text { liczbie kilometrów dróg }\end{array}$ & złe_drogi & $0,10 * * *$ & $0,08 * *$ & - \\
\hline $\begin{array}{l}\text { Udział pojazdów ciężkich w } \\
\text { ogóle pojazdów samocho- } \\
\text { dowych }\end{array}$ & UPC & $0,78 * *$ & $0,65 * * *$ & - \\
\hline $\begin{array}{l}\text { Wsk. zmotoryzowania } \\
\text { mieszkańców }\end{array}$ & zmot & $0,49 * * *$ & & - \\
\hline $\begin{array}{l}\text { Długość sieci drogowej } \\
\text { na } 100 \mathrm{~km}^{2} \text { powierzchni } \\
\text { regionu }\end{array}$ & drogi & $-0,28 * * *$ & $-0,26 * * *$ & $-0,70 * * *$ \\
\hline
\end{tabular}

$* * *$ - statystycznie istotne przy $1 \%$ poziomie istotności, ** - statystycznie istotne przy $5 \%$ poziomie istotności.

Źródło: opracowanie własne.

Drogi muszą być projektowane w taki sposób, aby cechować się odpowiednią hierarchizacją, w zależności od funkcji, jaką pełnią. Drogi tranzytowe nie powinny przechodzić przez obszar zabudowany. Przejście przez obszar zabudowany, jeśli nie da się tego rozwiązania uniknąć, powinno odbywać się w wydzielonych korytarzach, trwale odseparowanych od obszarów zabudowy i ruchu lokalnego tak, aby nie dochodziło do wymiany ruchu w jednym poziomie (Bohatkiewicz 2008). 
Zgodnie z oczekiwaniami zależność występująca pomiędzy stanem nawierzchni drogowej (złe_drogi) a analizowanymi wskaźnikami śmiertelności ma charakter dodatni. $Z$ raportów KRBRD wynika, iż „(...) błędy infrastruktury drogowej to jedna $\mathrm{z}$ głównych przyczyn powstawania wypadków drogowych i ich ciężkości (ofiar rannych i śmiertelnych)" (KRBRD 2013).

Przeprowadzone badania potwierdziły postawioną $\mathrm{w}$ badaniu hipotezę, iż niższa śmiertelność w wyniku wypadków drogowych charakteryzowała województwa, w których jednostki samorządowe dokonywały większych wydatków na infrastrukturę transportową (wydatki). W przypadku estymowania modeli 1 i 2 każde zwiększenie wydatków o jeden procent może przyczynić się do poprawy bezpieczeństwa na drogach przeciętnie o $0,11 \%$. Siła wpływu nie wydaje się być duża, jednak nakłady finansowe poniesione na poprawę bezpieczeństwa zwracają się nie tylko w postaci ograniczenia kosztów społecznych i materialnych, ale także kosztów budżetu państwa. Znacznie większa siła oddziaływania tej zmiennej, sięgająca $0,73 \%$, występuje w modelu 3, w którym szacowana jest ciężkość wypadków wyrażona jako liczba ofiar śmiertelnych przypadająca na 100 wypadków drogowych.

Kolejną zmienną istotną statystycznie we wszystkich modelach jest zmienna odpowiadająca długości infrastruktury drogowej przypadającej na $100 \mathrm{~km}^{2}$ powierzchni danego regionu. Zgodnie z oczekiwaniami wydłużenie sieci drogowej pozytywnie wpływa na poziom bezpieczeństwa drogowego, gdyż oznacza to płynną jazdę bez nadmiernego zatłoczenia dróg. Zjawisko kongestii jest bowiem źródłem nie tylko zwiększonej ilości spalin, ale także wywołuje zmęczenie, rozdrażnienie, a nawet agresję kierowców, co z kolei bezpośrednio przekłada się na zmniejszenie poziomu bezpieczeństwa.

\section{PODSUMOWANIE}

Poprawa poziomu bezpieczeństwa w ruchu drogowym, a zwłaszcza ograniczenie wskaźnika śmiertelności, stanowi przedmiot zainteresowania rządów wielu krajów. Rozwój motoryzacji i stale rosnąca potrzeba mobilności pomiędzy kontynentami przełożył się na traktowanie problemu nie tylko w skali lokalnej, ale także międzynarodowej. Doświadczenie pokazuje, iż wypadkom drogowym można zapobiec. Zasadniczymi czynnikami wspierającymi poprawę poziomu bezpieczeństwa są m.in.: organizacje międzynarodowe, programy krajowe, a także strategie oparte na wskaźnikach efektywności, które koncentrują się już na etapie planowania przestrzennego, projektowania transportu miejskiego oraz bezpiecznej infrastruktury drogowej. Nie bez znaczenia jest wprowadzanie nowych rozwiązań technologicznych, poprawa bezpieczeństwa pojazdów poprzez kontrolę stanu technicznego, wprowadzenie obowiązku stosowania pasów bezpieczeństwa i fotelików dla dzieci. Zmniejszenie zagrożenia w ruchu drogowym 
ma też być osiągnięte dzięki częstym kontrolom trzeźwości, zwiększeniu restrykcji w zakresie dozwolonej prędkości jazdy, a także kampaniom społecznym zwiększającym świadomość uczestników ruchu.

Na przestrzeni lat powstało wiele programów i dokumentów z zakresu BRD. W Polsce prace nad poprawą bezpieczeństwa na drogach trwają od lat 90 . Ich przejawem jest opracowanie programu Gambit 2000 (Ministerstwo Infrastruktury, 2005), a następnie jego nowelizacja w 2005 roku. Program zakładał, iż poprawa bezpieczeństwa ma być osiągnięta dzięki:

- kształtowaniu bezpiecznych zachowań uczestników ruchu drogowego, co ma przyczynić się do ograniczenia liczby przekroczeń dozwolonej prędkości oraz liczby pijanych kierowców o połowę w stosunku do stanu aktualnego. Z kolei zwiększenie stosowania pasów bezpieczeństwa ma ukształtować się na poziomie $95 \%$ z przodu pojazdu i $80 \%$ z tyłu pojazdu;

- poprawie infrastruktury drogowej i jej otoczenia, co ma mieć odzwierciedlenie w wyeliminowaniu $90 \%$ najbardziej niebezpiecznych miejsc na sieci drogowej, a także regulacji ruchu na $80 \%$ przejść tranzytowych tak. by ograniczyć liczbę ofiar śmiertelnych do 500, zaś wskaźnika śmiertelności na skutek wypadków drogowych do 12 osób na $1 \mathrm{mln}$ pojazdokilometrów;

- ochronie pieszych, dzieci oraz rowerzystów tak, by liczba ofiar tej grupy uczestników ruchu nie przekraczała $30 \%$ wszystkich zabitych na drogach i by wskaźnik śmiertelności był niższy niż 22 osoby na 1 mln mieszkańców;

- zmniejszeniu ciężkości i konsekwencji wypadków drogowych tak, by liczba ofiar śmiertelnych na 100 wypadków ukształtowała się na poziomie nie wyższym niż 5 osób na 100 pojazdów;

- usprawnieniu systemu BRD, które ma być osiągnięte dzięki stworzeniu warunków do prowadzenia długofalowych działań na rzecz poprawy BRD.

Należy jednak pamiętać, że zdarzenia drogowe nie są następstwem jedynie niewłaściwej, niedoinwestowanej infrastruktury, lecz również niewłaściwego zachowania uczestników ruchu drogowego. Jazda pod wpływem alkoholu, nadmierna brawura, niedostateczne umiejętności kierowców czy jazda bez kasku to tylko niektóre z zachowań kierowców prowadzących do nieszczęścia.

Wyniki otrzymane $\mathrm{w}$ niniejszym badaniu potwierdziły wnioski płynące z raportu KRBRD. Artykuł nie wyczerpuje jednakże tematu. Wszystkie formy działalności człowieka związane są z przestrzenią, w kolejnym etapie badania zostanie zatem podjęta próba wzbogacenia modelu o interakcje przestrzenne.

\section{BIBLIOGRAFIA}

Anbarci N., Escaleras M., Register C. (2006), Traffic fatalities and public sectror corrupion, "Kyklos", vol. 59, nr 3.

Bohatkiewicz J., Biernacki S., Drach M., Kozłowski D., Nowak P. (2008), Zasady uspokajania ruchu na drogach za pomoca fizycznych środków technicznych, Biuro Ekspertyz i Budownictwa Komunikacyjnego „EKKOM”, Kraków. 
Castillo-Manzano J.I. (2014), Could being in the European Union save lives? An econometric analysis of the $3^{\text {rd }}$ European Road Safety Action Program, http://www.ub.edu/graap/ europeization.pdf.

Dańska-Borsiak B. (2011), Dynamiczne modele panelowe $w$ badaniach ekonomicznych, Wydawnictwo Uniwersytetu Łódzkiego, Łódź.

Domańska A. (2006), Wplyw infrastruktury transportu drogowego na rozwój regionalny, Wydawnictwo Naukowe PWN, Warszawa.

Jaździk-Osmólska A. (2013), Metoda oraz wycena kosztów wypadków i kolizji drogowych na sieci dróg w Polsce na koniec 2012 roku z wyodrębnieniem średnich kosztów społeczno-ekonomicznych zdarzeń drogowych na sieci TEN-T, Instytut Badawczy Dróg i Mostów, Zakład Ekonomiki, Warszawa.

Komenda Główna Policji (2005), Wypadki drogowe w Polsce w 2004 roku, Biuro Taktyki Zwalczania Przestępczości. Wydział Analiz Przestępczości, Warszawa.

Komenda Główna Policji (2006), Wypadki drogowe w Polsce w 2005 roku, Warszawa.

Komenda Główna Policji (2007), Wypadki drogowe w Polsce w 2006 roku, Biuro Prewencji i Ruchu Drogowego. Wydział Profilaktyki w Ruchu Drogowym, Warszawa.

Komenda Główna Policji (2008), Wypadki drogowe w Polsce w 2007 roku, Biuro Prewencji i Ruchu Drogowego. Wydział Profilaktyki w Ruchu Drogowym, Warszawa.

Komenda Główna Policji (2009), Wypadki drogowe w Polsce w 2008 roku, Biuro Ruchu Drogowego. Wydział Profilaktyki i Analiz, Warszawa.

Komenda Główna Policji (2010), Wypadki drogowe w Polsce w 2009 roku, Biuro Ruchu Drogowego. Wydział Profilaktyki i Analiz, Warszawa.

Komenda Główna Policji (2011), Wypadki drogowe w Polsce w 2010 roku, Biuro Ruchu Drogowego. Zespół Profilaktyki i Analiz, Warszawa.

Komenda Główna Policji (2012), Wypadki drogowe w Polsce w 2011 roku, Biuro Ruchu Drogowego. Zespół Profilaktyki i Analiz, Warszawa.

Komenda Główna Policji (2013), Wypadki drogowe w Polsce w 2012 roku, Biuro Ruchu Drogowego. Zespół Profilaktyki i Analiz, Warszawa.

Kopits E., Cropper M. (2003), Traffic fatalities and economic growth, "Policy Research Working Paper" nr 3035.

Koren C., Borsos A. (2013), From increasing to decreasing fatality figures: where is a turning point?, "Proceedings of the Eastern Asia Society for Transportation Studies", vol. 9.

Krajowa Rada Bezpieczeństwa Ruchu Drogowego (2013), Narodowy program Bezpieczeństwa Ruchu Drogowego 2013-2020, Materiał na posiedzenie plenarne KRBRD w dniu 08.01.2013.

Kufel T. (2007), Rozwiąywanie problemów z wykorzystaniem programu GRETL, Wydawnictwo Naukowe PWN, Warszawa.

Maddala G.S. (2008), Ekonometria, Wydawnictwo Naukowe PWN, Warszawa.

Ministerstwo Infrastruktury, Krajowy Program Bezpieczeństwa Ruchu Drogowego 2005-20072013. GAMBIT 2005, Dokument przyjęty przez Radę Ministrów na posiedzeniu w dniu 19.04.2005.

Rajchel K., Nowakowski Z. (2006), Pojęcie wypadku drogowego i system ewidencji, „Zeszyty Naukowe Politechniki Rzeszowskiej”, z. 7, Rzeszów.

Schreyer D., Schneider Ch., Maibach M., Rothengatter W., Doll C., Schmedding D. (2004), External costs of transport. Update study. Final Report, INTRANS/IWW, Zurich-Karlsruhe.

Wachnicka J., Smolarek L. (2013), Model of multilevel stochastic analysis of road safety on regional level, "Reliability: Theory \& Applications" 8(29), s. 39-48.

WHO (2013), Global status report on road safety. Time for action, Genewa.

http://ec.europa.eu/transport/road_safety/index_en.htm.

http://stat.gov.pl/. 
Anna Danuta Weszczak

\title{
APPLYING PANEL DATA MODELS TO ESTIMATE ROAD SAFETY IN POLAND IN 2001-2012
}

\begin{abstract}
This paper presents econometric model for road safety in different regions of Poland in 2001-2012. The study is an attempt to indicate the socio-economic determinants of road safety. On the basic of literature and reports of institutions studied the issue and taking into account the data availability following variables were considered: the expenditure of local governments in Department 600 - Transportation and communication, roads quality, motorization rate, length of road network and share of heavy vehicles in all vehicles. The study was conducted for three different risk indictors: number of fatalities per 1 million inhabitants, number of fatalities per 1 million vehicles and number of fatalities per 100 road accidents. Panel data models - fixed effect model (FEM) and random effects model (REM) were used to estimate parameters of equation.
\end{abstract}

Keywords: transport, road safety, panel data models.

JEL: C23, R41. 